\title{
A Correlational Analysis between Self-Control and Student's Video Game Performance in Panabo City
}

\author{
Pamela Dela Cerna ${ }^{1}$, Noreen Mae Malinao ${ }^{2}$, Jannie Jenny Mahipos ${ }^{3}$, Glendell Razon Jadraque ${ }^{4}$, Mark Van M. \\ Buladaco ${ }^{5}$ \\ ${ }^{1,2,3}$ Student, Bachelor of Science in Information Technology, Davao Del Norte State College, Philippines \\ ${ }^{4,5}$ Faculty, Davao Del Norte State College
}

\begin{abstract}
As technology continuously advancing in today's era, electronic technologies became one of the creations that most people need for communication. They deemed a kind of leisure or recreational tool such that Video Games. In some studies, selfcontrol seems strongly associated with counterproductive behavior, but not much research about video game performance. Thus, a lack of knowledge concerning the influence of self-control on video game performance is present. This research aims to analyze the correlation between an individual's self-control and the student's video game performance in Panabo City. The questionnaire splits into three parts: Students' demographic profile, Students Self-Control, and Students Video Game Performance. In participants, 32 of the respondents participated in the study-researchers used quantitative non-experimental correlational research design to approach the research question. In the result, the mean level of students' self-control is $\mathbf{3 . 2 1 8 8}$ with a standard deviation of 0.38882 . It shows that the level of students' self-control is moderate while the mean level of students' video game performance is $\mathbf{3 . 5 0 4 2}$ with a standard deviation of 0.46062 . It shows that the level of students' video game performance is high. The researchers concluded that there is no significant relationship between students' self-control and video game performance, showing a weak positive relationship.
\end{abstract}

Keywords: Correlational Research, Panabo City, Self-Control, Video Games Performance

\section{INTRODUCTION}

\section{A. Background of the Study}

O elf-control affects, among other things, individuals' performance and behavior. From doing simple tasks to academic performance to work performance, affect by selfcontrol. The individual differences construct of self-control has been found to predict a wide range of criteria [4]. For the two domains, its significance was predominantly considered. On the one hand, high self-control associates with better scores of individual performance [4].

On the other hand, low self-control seems strongly associated with counterproductive behavior [4] - nevertheless, not much research about video game performance. Thus a lack of knowledge concerning the influence of self-control on video game performance is present.

It sparked the researchers' curiosity and hunger for knowledge. This particular study also focuses on knowing if there is a connection between a person's self-control and the student's video game performance. The lack of knowledge upon this topic also means that this study could potentially be the basis for future studies centered on this subject matter.

As technology arises in this century, many electronic technologies were developed, such as Video Games. It used to be deemed a kind of leisure or recreational tool and embraced by the general public, children, and teenagers [1]. During video games, users interact with electronic devices that influence the players to understand decision-making and their interaction with the game [2].

Game performance, which differs between a newbie and a veteran, pretty much tests a skill level. One would say it reflects both the conscious and subconscious parts of the human mind of their self-control, and it becomes a basis of what will dictate their decisions inside the game. However, in some fighting games, specifically Street Fighter, a particular playstyle that feeds on the most basic and most intuitive style was mainly made. The "Flowchart Ken," a game strategy based on individual choices, would become a game war of patterns once memorized; thus, when it becomes autonomous and reflexive, no wits have ever been laid.

In some other games, autonomous nature also falls within some categories like Bullet Hell. In bullet hell games, the decisions sometimes seem nearly non-existent; it only exists to shoot without reload and dodge the bullets in a timed fashion; once practiced; it becomes effortless as if it became a second reflex. It became non-logical and became reflexive, a thing drawn from a patterned yet in the subconscious. [3] In the Canadian Medical Education Journal, it states that there are two systematic types of thinking. The first one referring to sub-consciousness, a method of thinking without thinking; System 1 is also defined as a reflex system, which is intuitive, experiential, or pattern recognition, triggering an automatic mode of thinking.

System 2, on the other hand, is the complete turnaround of System 1, as System 1 is a subconscious reflex, the System 2 deals with the conscious, careful, and analytical state of mind. The awareness of a decision is pieced together by a mental search of both information and experience [3]. When people, especially students, play not in their right state of mind without clarity, they become less analytical, therefore having low self-control. System 1 takes place in their primitive state to lash out unconsciously, and some may verbally or might 
physically go out of control and often comes later in regret. However, despite its downsides, one cannot deny System 1 still serves as a defense mechanism to move faster than our conscious mind will be. As a functional and rational being, System 2 serves to help us differently from System 1. It keeps us in check. It helps us decide analytically and be conscious of controlling ourselves, whether in a game or outside of it.

\section{B. Theoretical Framework}

Good self-control correlated with several positive outcomes associated with health, success, wellbeing, and crime rejection [4]. Policy-makers have thought of large-scale programs aimed toward rising self-control with the hope of raising the health and wealth of the grouping and reducing crime [5]. Vital to the current study is the link between self-control and video game performance.

Self-control has been remarked as self-regulation, selfdiscipline, and willpower, among alternative names. In a research study of Duckworth and his team, they acknowledged the confusion between which means of self-management and self-regulation and differentiate them as "self-control." Selfcontrol is a temperament attribute that voluntarily regulates impulses to meet long-run goals, and "self-regulation" being metacognitive methods that facilitate personal meeting goals [6]. Similar tries to tell apart between the two area units delineated in McCullough and Willoughby's research in 2009 [7]. In Storch's research, he claimed that self-control and selfregulation are compactly set apart by saying, "self-control helps you meet small challenges, but you will need selfregulation to change your life significantly." [7].

Central to their definition of self-control is the power to override or alter one's inner reactions, disrupt and refrain from acting on unsought behavioral urges (such as impulses). Storch's study believes that self-control encompasses four domains: dominant thoughts, emotions, impulse, and performance. His analysis in self-control targeted the subsequent domains: achievement and task performance (school and work), impulse management, psychological adjustment (symptoms of anxiety, depression, and obsessivecompulsive behavior), social relationships, and moral emotions (shame and guilt).

Recent research suggests that playing video games, even for a comparatively short amount of time, improves performance on various tasks that measure visual and attentional abilities. A variety of studies have found that having participants play action video games for as few as ten $h$ will improve performance on laboratory tasks that, on the surface, are dissimilar to the games they play [8]. Thus, video game experience improves the necessary skills that adapt to novel tasks and stimuli. Playing video games such as Donkey Kong and Pac Man improved older adults' reaction times compared to controls who did not play [8].

\section{Conceptual Framework}

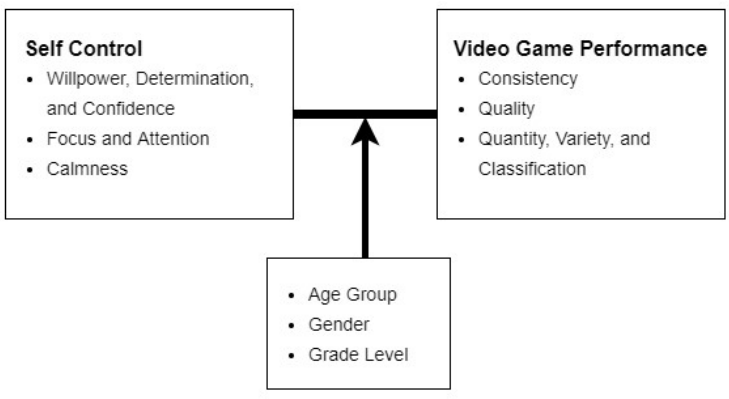

Figure 1: Conceptual Framework of the Study

Figure 1 presents the conceptual model does it utilize in this study. This diagram shows the relationship between selfcontrol and high school students' video game performance in Panabo City. The standard graph shows what will be the process to answer these research problems. The left side represents the independent variable that contains its indicators to be discussed and explored; meanwhile, the right side represents the dependent variable to test if both variables have a relationship or difference.

\section{Research Questions}

The main research questions that guided this research study are:

1. RQ1. What is the demographic profile of the participants of the study in terms of?

\subsection{Age Group \\ 1.2 Gender \\ 1.3 Grade Level}

2. RQ2. What is the level of students' self-control in terms of:

2.1Willpower, Determination, and Confidence

\subsection{Focus and Attention}

\subsection{Calmness}

3. RQ3. What is the level of students' video game performance in terms of?

\subsection{Consistency}

\subsection{Quality}

\subsection{Quantity, Variety, and Classification}

4. RQ4. Is there a significant difference in the level of student's self-control when grouped according to:

\subsection{Age Group \\ 4.2 Gender \\ 4.3 Grade Level}

5. RQ5. Is there a significant difference in the student's video game performance when grouped according to: 


\subsection{Age Group}

\subsection{Gender}

\subsection{Grade Level}

6. RQ6. Is there a significant relationship between self-control and students' video game performance?

\section{Null Hypothesis}

Ho1: There is no significant difference in the level of student's self-control when grouped according to:
a. Gender
b. Age Group
c. Grade Level

Ho2: There is no significant difference in the level of student's video game performance when grouped according to:
a. Gender
b. Age Group
c. Grade Level

Ho3: There is no significant relationship between the students' self-control and students' video game performance.

\section{METHODOLOGY}

The purpose of this study is to determine if there is a relationship between self-control of High School students in Panabo City and their performance in playing games. This chapter is organized into the following sections: research design, research locale, participants of the study, sampling techniques, statistical techniques, data collection procedure, research instrument and ethical considerations.

\section{A. Research Design}

The study approached the research questions from a quantitative non-experimental correlational research design perspective. The research uses surveys to collect data on the correlation between self-control and the student's video game performance.

Correlation research design is a statistical measure of a relationship between two or more variables, indicates how one variable may predict another. The descriptive techniques discussed above permit a statement about that relationship in the form of correlations [9]. Findings from correlational research may assess prevalence and relationships from current data and analysis between variables and predicted events. Despite its many uses, prudence is required when using the methodology and analyzing data. Important issues single out for discussion, and several options are put forward for analyzing data to help researchers reduce mistakes [10].

For this study, the variables involved were self-control and the student's video game performance. Quantitative research aims to investigate, count or classify, and construct statistical models and figures to explain the observation. A correlational research study describes what exists between variables and systematically investigates relationships between two or more interest variables [11].

This design was selected to determine if there is a relationship between self-control and video game performance among High School students in Panabo City.

\section{B. Research Locale}

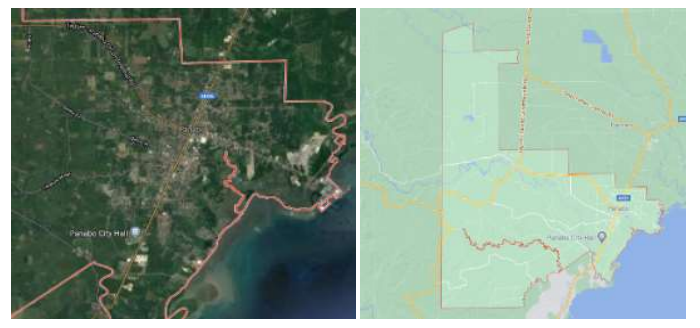

Figure 2: Research Locale

The study was conducted within Panabo City, Davao Del Norte since the chosen respondents were high school students from Panabo City.

\section{Participants of the Study}

The respondents of the study are High School students from different schools in Panabo City. The researchers drew the respondents by using snowball sampling.

They were designated according to their Gender and Year level. The researchers gave sets of a survey questionnaire to the respondents that were being assessed.

\section{Sampling Techniques}

To address the research questions, it is certain that the researcher should gather data from all cases. Thus, there is a need, therefore, to select a sample. The entire set of cases from which the sample researcher sample is drawn is called the population. As researchers do not have the time or resources to examine the population as a whole, they use a sampling technique to minimize the number of cases [12]. The researchers chose to use Convenience Sampling as the appropriate sampling technique for this research study. Convenience sampling tends to be a favored sampling technique among students as it is inexpensive and an easy option compared to other sampling techniques [13]. Convenience sampling also helps overcome many of the research-related limitations. For example, using friends or family as part of the sample is more comfortable than targeting unknown individuals [12]. As the name implies, Convenience sampling is convenient.

The sample size is one of the research design elements that researchers need to consider as they plan their study. In quantitative research measures variables and generalizes data obtained from a representative sample from the total population [14]. It is also scientifically essential to estimate the sample size before performing a study or at the early stage of a study to optimize the probability of detecting any existing 
relevant correlations [15]. This study's sample size is estimated to be more than 50 students, composed of Junior and Senior High School students in Panabo City.

\section{E. Statistical Treatments}

The researchers will use IBM SPSS Statistics to analyze data gathered from the respondents. The researchers will ask assistance from the statistician to analyze and interpret the result utilizing appropriate statistical tools. The researchers use:

1. Frequency and Percentage Distribution - used to determine the central tendency of the demographic profile of the respondent, such as their age group, gender, and grade level. Below is the formula to calculate the distribution:

$P=(f / n) \times 100$

Where:

$\mathrm{P}=$ total number of percentage

$\mathrm{f}=$ frequency

$\mathrm{n}=$ number of total cases

2. T-test - used to determine the analysis of the means of two groups involved in the data sets. To calculate the T-test, the formula is:

$t=\frac{\overline{x_{1}}-\overline{x_{2}}}{\overline{S_{1}^{2}}+\frac{S_{2}^{2}}{N_{1}}}$

Where:

$\overline{x_{1}}=$ mean of the first dataset

$\overline{x_{2}}=$ mean of the second dataset

$S_{1}^{2}=$ standard deviation of the first dataset

$S_{2}^{2}=$ standard deviation of the second dataset

$N_{1}=$ over-all number of elements in the first dataset

$N_{2}=$ over-all number of elements in the second dataset

3. ANOVA - a statistical procedure used to analyze or compare the means of two variables. A statistical tool that tests and interprets the significance between variables rejects the null hypothesis or accepts the alternative hypothesis. Below is the formula:

$$
F=\frac{M S T}{M S E}
$$

Where:

$\mathrm{F}=$ ANOVA Coefficient

MST = mean of squared deviations due to treatments

MSE $=$ mean of squared deviations due to error.
The formula for MST is:

$$
M S T=\frac{S S T}{p-1}
$$

$$
S S T=\sum n(X-\overline{\mathrm{X}})^{2}
$$

Where:

SST $=$ the total sum of squares due to treatment

$\mathrm{p}=$ Total number of populations

$\mathrm{n}=$ the entire-sample size of the population

The formula for MSE is:

$$
\begin{gathered}
M S E=\frac{S S E}{N-p} \\
S S E=\sum(n-1) S^{2}
\end{gathered}
$$

Where:

SSE $=$ the total sum of squares due to error

$\mathrm{S}=$ Standard deviation of the samples

$\mathrm{n}=$ Total number of observations.

4. Pearson $r$ - It is regarded as the best way to calculate the relation between variables. It gives information about the magnitude of the association, correlation, and the direction of the relationship between two variables. The formula is:

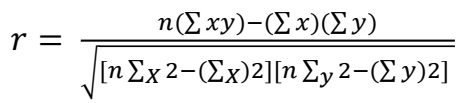

Where:

$\mathrm{n}=$ total sample size of paired scores

$\Sigma x y=$ sum of the products of scores

$\Sigma \mathrm{x}=$ sum of $\mathrm{x}$ scores

$\Sigma \mathrm{y}=$ sum of $\mathrm{y}$ scores

$\Sigma \mathrm{x}^{2}=$ sum of squared $\mathrm{x}$ scores

$\Sigma \mathrm{y}^{2}=$ sum of squared y scores

\section{F. Data Collection Procedure}

The researchers' utilized a survey instrument for data gathering. Surveys are effective in that many variables to measure without substantially increasing the time or cost. Survey data can be obtained from several reasonably low cost and relatively quickly, depending on the survey's nature. Researchers have also found increased participation by respondents when deployed with online surveys rather than answering a lengthy question [16]. The survey questioners for this study were given either online or offline to the High School students of Panabo City due to their different circumstances. 


\section{G. Research Instrument}

Researchers use those methods in collecting their desired data, known as research or measurement instruments [17]. The term research instrument refers to any tool that a researcher may use to collect or obtain data, measure data, and analyze data relevant to the subject of the research [18].

The research instrument must answer the research aims, objectives, and research questions and prove or disprove the study's hypothesis. A research instrument's format may consist of questionnaires, surveys, interviews, checklists, or simple tests. The researcher will determine the choice of which research instrument to use. It will also be strongly related to the actual methods used in the specific study [18].

A research-made questionnaire checklist to collect the necessary data for the student's profile was the instrument used in this analysis. The questionnaire's draft was drawn out supported the researcher's readings, previous studies, and published studies relevant to the present study.

\section{H. Ethical Considerations}

Research ethics govern how scientific and other research is carried out and disseminated in research institutions such as universities [19].

For researchers and participants, upholding ethical standards and values has many advantages. Firstly, they help promote the research's general aims, such as searching for knowledge and the intention to avoid an error. Secondly, ethics promote principles, including respect, trust, and transparency, fundamental to effective collaboration. Thirdly, they are essential in holding researchers accountable to societies and communities, building public trust, and supporting research [20].

In this research study, the researchers ensured the participants' rights in invading their privacy without consent from them. The research did not attempt to pry beyond what is needed in their personal lives, and that all data obtained from them was acknowledged and clearly represented.

\section{RESULTS AND DISCUSSIONS}

The study outcome is discussed in this chapter. All of the participants in this survey are students in Panabo City. The presentation of data in this research study are arranged in the following sequence: The demographic profile of the participants of the study in terms of Age Group, Gender \& Grade Level, the level of students' Self-control in terms of, Willpower, Determination and Confidence, Focus and Attention \& Calmness, the Level of students' Video Game Performance in terms of, Consistency, Quality \& Quantity, Variety, and Classification, a significant difference in the student's self-control when grouped according to, Age Group, Gender \& Grade Level, a substantial difference in the level of students' video game performance when grouped according to, Age Group, Gender \& Grade Level and a significant relationship between self-control and students video game performance in Panabo City.

RQ1. What is the demographic profile of the participants of the study in terms of Age Group, Gender, and Grade Level?

There is a total of 32 participants in the study composed of nineteen males and thirteen females. The highest percentages of respondents are from the age group of 15 to 18 years old in participants. Among the level of participants from Grade 8 to 12, Grade 12 represents the highest rate. Figure 3, 4 and 5 demonstrate these findings.

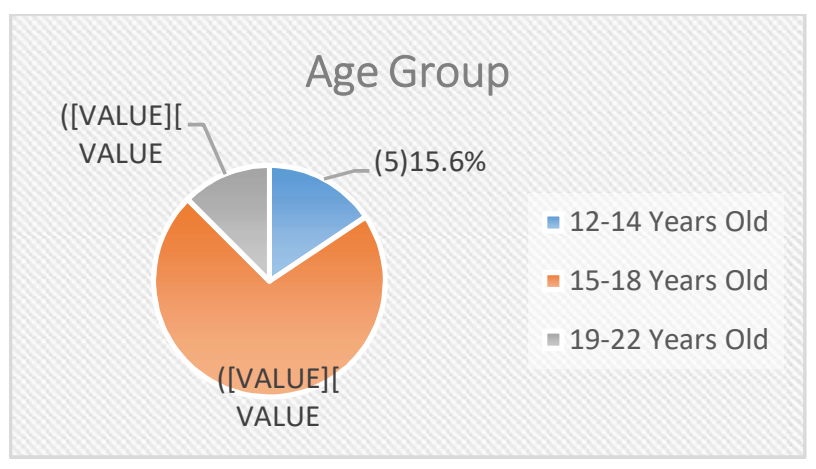

Figure 3. Age Group

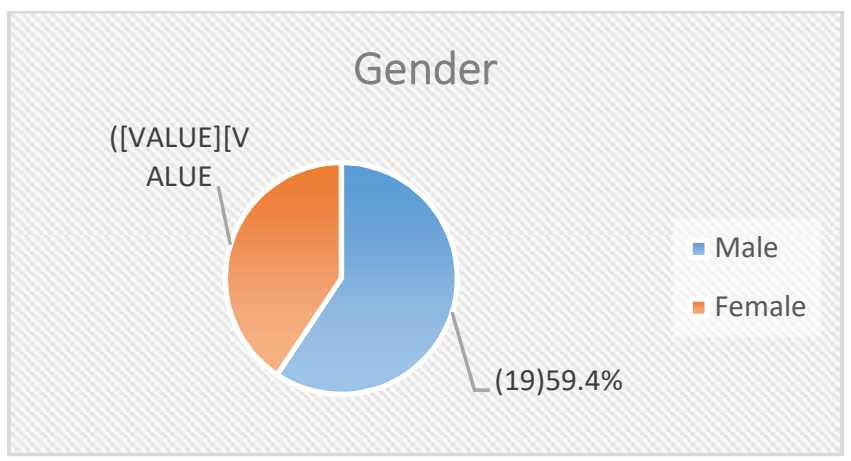

Figure 4. Gender

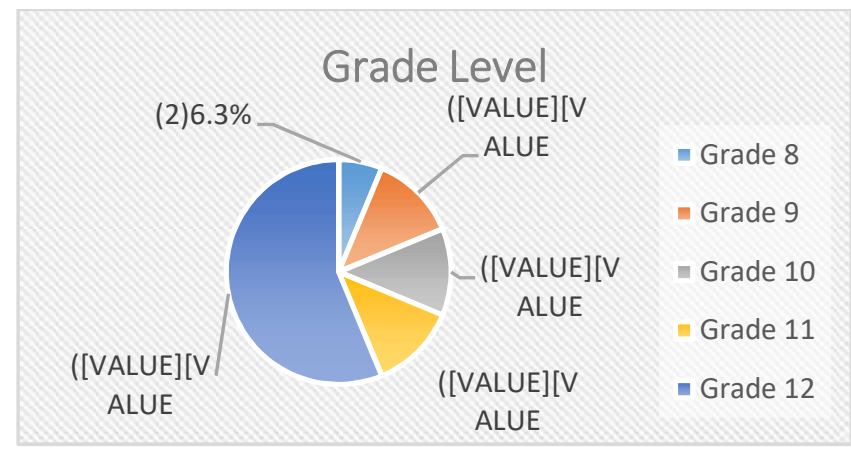

Figure 5. Grade Level

RQ2. What is the Level of Student's Self-control in Willpower, Determination and Confidence, Focus and Attention, and Calmness?

Table I shows the Level of Student's Self-control. The means of the level of willpower, determination, and confidence of the 
respondents is 3.2688 with a standard deviation of 0.48356 . This shows that the willpower, determination, and confidence of the respondents is moderate. Moreover, the respondents' level of focus and attention is 3.2000 with a standard deviation of 0.52302 . It shows that the focus and attention of the respondents are moderate.

The means the level of calmness of the respondents is 3.1875 with a standard deviation of 0.69456 . It shows that the calmness of the respondents is moderate. Therefore, the mean level of students' self-control is 3.2188 with a standard deviation of 0.38882 . This shows that the level of students' self-control is moderate.

Table I: Level of Student's Self-Control

\begin{tabular}{|c|c|c|c|c|c|}
\hline & $\mathrm{N}$ & $\begin{array}{c}\text { Minimu } \\
\mathrm{m}\end{array}$ & Maximum & Mean & $\begin{array}{c}\text { Std. } \\
\text { Deviation }\end{array}$ \\
\hline WDC & 32 & 2.20 & 4.20 & 3.2688 & .48356 \\
\hline FA & 32 & 2.20 & 4.20 & 3.2000 & .52302 \\
\hline Cal & 32 & 1.40 & 4.40 & 3.1875 & .69456 \\
\hline SSC & 32 & 2.60 & 4.07 & 3.2188 & .38882 \\
\hline $\begin{array}{c}\text { Valid N } \\
\text { (listwis } \\
\text { e) }\end{array}$ & 32 & & & & \\
\hline
\end{tabular}

RQ3. What is the Level of Student's Video Game Performance in Consistency, Quality, Quantity, Variety, and Classification?

Table II shows the Level of Student's Video Game Performance. The means the level of consistency of the respondents is 3.6250 with a standard deviation of 0.57418 . It shows that the consistency of the respondents is high. The means the level of quality of the respondents is 3.3250 with a standard deviation of 0.55124 . It shows that the level of quality of the respondents is moderate.

The means the level of quantity, variety, and classification of the respondents is 3.5625 with a standard deviation of 0.58901 . It shows that the level of quantity, variety, and classification of the respondents is high. Therefore, overall, the mean level of students' video game performance is 3.5042 with a standard deviation of 0.46062 . This shows that the level of students' video game performance is high.

Table II: Level of student's video game performance.

\begin{tabular}{|c|c|c|c|c|c|}
\hline & $\mathrm{N}$ & Minimum & Maximum & Mean & $\begin{array}{c}\text { Std. } \\
\text { Deviation }\end{array}$ \\
\hline Con & 32 & 2.80 & 4.80 & 3.6250 & .57418 \\
\hline Q & 32 & 2.40 & 4.20 & 3.3250 & .55124 \\
\hline QVC & 32 & 2.40 & 5.00 & 3.5625 & .58901 \\
\hline SVGP & 32 & 2.87 & 4.40 & 3.5042 & .46062 \\
\hline $\begin{array}{c}\text { Valid } \\
\text { N } \\
\text { (listwi } \\
\text { se) }\end{array}$ & 32 & & & & \\
\hline
\end{tabular}

RQ4. Is there a significant difference in the student's selfcontrol when grouped according to Age Group, Gender, and Grade Level?

Table III shows the significant difference in the student's selfcontrol when group according to age. Since the p-value is $0.619>0.05$, then we do not reject the null hypothesis. There is no significant difference in the students' self-control when grouped according to age. It means that the self-control of students does not vary with age.

Table III: Significant Difference in the Student's Self-Control When Group according To Age Using ANOVA

\begin{tabular}{|c|c|c|c|c|c|c|}
\hline & & $\begin{array}{l}\text { Sum of } \\
\text { Squares }\end{array}$ & $\mathrm{df}$ & $\begin{array}{c}\text { Mean } \\
\text { Square }\end{array}$ & $\mathrm{F}$ & Sig. \\
\hline \multirow{3}{*}{ WDC } & $\begin{array}{c}\text { Between } \\
\text { Groups }\end{array}$ & . 161 & 2 & .081 & .330 & .722 \\
\hline & $\begin{array}{l}\text { Within } \\
\text { Groups } \\
\end{array}$ & 7.087 & 29 & . 244 & & \\
\hline & Total & 7.249 & 31 & & & \\
\hline \multirow{3}{*}{ FA } & $\begin{array}{c}\text { Between } \\
\text { Groups }\end{array}$ & 2.624 & 2 & 1.312 & $\begin{array}{c}6.49 \\
7\end{array}$ & .005 \\
\hline & $\begin{array}{l}\text { Within } \\
\text { Groups } \\
\end{array}$ & 5.856 & 29 & .202 & & \\
\hline & Total & 8.480 & 31 & & & \\
\hline \multirow{3}{*}{ Cal } & $\begin{array}{c}\text { Between } \\
\text { Groups }\end{array}$ & .723 & 2 & .361 & .736 & .488 \\
\hline & $\begin{array}{l}\text { Within } \\
\text { Groups } \\
\end{array}$ & 14.232 & 29 & .491 & & \\
\hline & Total & 14.955 & 31 & & & \\
\hline \multirow{3}{*}{$\mathrm{SSC}$} & $\begin{array}{c}\text { Between } \\
\text { Groups }\end{array}$ & . 152 & 2 & .076 & .488 & .619 \\
\hline & $\begin{array}{l}\text { Within } \\
\text { Groups }\end{array}$ & 4.534 & 29 & . 156 & & \\
\hline & Total & 4.687 & 31 & & & \\
\hline
\end{tabular}

Table IV shows the significant difference in the student's selfcontrol when group according to gender. Since the p-value is $0.105>0.05$, the null hypothesis will not be rejected. Therefore, there is no significant difference in the students' self-control when grouped according to gender. It shows that it is not the basis for the student's self-control, whether an individual is male or female.

Table IV: Significant difference in the student's self-control when group according to gender using ANOVA

\begin{tabular}{|c|c|c|c|c|c|c|}
\hline & & $\begin{array}{l}\text { Sum of } \\
\text { Squares }\end{array}$ & $\mathrm{df}$ & $\begin{array}{c}\text { Mean } \\
\text { Square }\end{array}$ & $\mathrm{F}$ & Sig. \\
\hline \multirow{3}{*}{ WDC } & $\begin{array}{c}\text { Between } \\
\text { Groups }\end{array}$ & .106 & 1 & .106 & .447 & .509 \\
\hline & $\begin{array}{l}\text { Within } \\
\text { Groups }\end{array}$ & 7.142 & 30 & .238 & & \\
\hline & Total & 7.249 & 31 & & & \\
\hline \multirow{3}{*}{ FA } & $\begin{array}{c}\text { Between } \\
\text { Groups }\end{array}$ & .187 & 1 & .187 & .675 & .418 \\
\hline & $\begin{array}{l}\text { Within } \\
\text { Groups }\end{array}$ & 8.293 & 30 & .276 & & \\
\hline & Total & 8.480 & 31 & & & \\
\hline \multirow{2}{*}{$\mathrm{Cal}$} & $\begin{array}{c}\text { Between } \\
\text { Groups }\end{array}$ & 1.296 & 1 & 1.296 & 2.846 & .102 \\
\hline & Within & 13.659 & 30 & .455 & & \\
\hline
\end{tabular}




\begin{tabular}{|c|c|c|c|c|c|c|}
\hline \multirow{4}{*}{} & Groups & & & & & \\
\cline { 2 - 7 } & Total & 14.955 & 31 & & & \\
\hline \multirow{3}{*}{ SSC } & $\begin{array}{c}\text { Between } \\
\text { Groups }\end{array}$ & .400 & 1 & .400 & 2.796 & .105 \\
\cline { 2 - 7 } & $\begin{array}{c}\text { Within } \\
\text { Groups }\end{array}$ & 4.287 & 30 & .143 & & \\
\cline { 2 - 7 } & Total & 4.687 & 31 & & & \\
\hline
\end{tabular}

Table V shows the significant difference in the student's selfcontrol when group according to grade level. Since the p-value is $0.468>0.05$, then we do not reject the null hypothesis. There is no significant difference in the students' self-control when grouped according to grade level. It shows that the student's self-control will not differ regarding which grade level the student is.

Table V: Significant difference in the student's self-control when group according to grade level using ANOVA

\begin{tabular}{|c|c|c|c|c|c|c|}
\hline & & $\begin{array}{l}\text { Sum of } \\
\text { Squares }\end{array}$ & $\mathrm{df}$ & $\begin{array}{c}\text { Mean } \\
\text { Square }\end{array}$ & $\mathrm{F}$ & Sig. \\
\hline \multirow{3}{*}{$\begin{array}{l}\text { W } \\
\text { D } \\
\text { C }\end{array}$} & $\begin{array}{c}\text { Between } \\
\text { Groups }\end{array}$ & 1.519 & 4 & .380 & $\begin{array}{c}1.78 \\
9 \\
\end{array}$ & .160 \\
\hline & $\begin{array}{l}\text { Within } \\
\text { Groups }\end{array}$ & 5.730 & 27 & .212 & & \\
\hline & Total & 7.249 & 31 & & & \\
\hline \multirow{3}{*}{$\begin{array}{l}\mathrm{F} \\
\mathrm{A}\end{array}$} & $\begin{array}{c}\text { Between } \\
\text { Groups }\end{array}$ & 1.502 & 4 & .376 & $\begin{array}{c}1.45 \\
3\end{array}$ & .244 \\
\hline & $\begin{array}{l}\text { Within } \\
\text { Groups }\end{array}$ & 6.978 & 27 & .258 & & \\
\hline & Total & 8.480 & 31 & & & \\
\hline \multirow{3}{*}{$\begin{array}{c}\mathrm{Ca} \\
1\end{array}$} & $\begin{array}{c}\text { Between } \\
\text { Groups }\end{array}$ & .751 & 4 & .188 & .357 & .837 \\
\hline & $\begin{array}{l}\text { Within } \\
\text { Groups }\end{array}$ & 14.204 & 27 & .526 & & \\
\hline & Total & 14.955 & 31 & & & \\
\hline \multirow{3}{*}{$\begin{array}{l}\mathrm{SS} \\
\mathrm{C}\end{array}$} & $\begin{array}{c}\text { Between } \\
\text { Groups }\end{array}$ & .561 & 4 & .140 & .918 & .468 \\
\hline & $\begin{array}{l}\text { Within } \\
\text { Groups }\end{array}$ & 4.126 & 27 & .153 & & \\
\hline & Total & 4.687 & 31 & & & \\
\hline
\end{tabular}

RQ5. Is there a substantial difference in the Level of Students' Video Game Performance when grouped according to Age Group, Gender, and Grade Level?

Table VI shows the ANOVA test of the significant difference in the students' video game performance when group according to age. Since the p-value is $0.320>0.05$, then we do not reject the null hypothesis. There is no significant difference in students' video game performance when grouped according to age. It means students' video game performance will not base on what extent the person's age.

Table VI: Significant difference in the student's video game performance when group according to age using ANOVA

\begin{tabular}{|c|c|c|c|c|c|c|}
\hline \multicolumn{2}{|l|}{} & $\begin{array}{c}\text { Sum of } \\
\text { Squares }\end{array}$ & df & $\begin{array}{c}\text { Mean } \\
\text { Squar } \\
\text { e }\end{array}$ & F & Sig. \\
\hline Con & Between & .179 & 2 & .089 & .258 & .774 \\
\hline
\end{tabular}

\begin{tabular}{|c|c|c|c|c|c|c|}
\hline & Groups & & & & & \\
\hline & $\begin{array}{l}\text { Within } \\
\text { Groups }\end{array}$ & 10.041 & 29 & .346 & & \\
\hline & Total & 10.220 & 31 & & & \\
\hline \multirow{3}{*}{ Q } & $\begin{array}{c}\text { Between } \\
\text { Groups }\end{array}$ & .284 & 2 & .142 & .451 & .642 \\
\hline & $\begin{array}{l}\text { Within } \\
\text { Groups }\end{array}$ & 9.136 & 29 & .315 & & \\
\hline & Total & 9.420 & 31 & & & \\
\hline \multirow{3}{*}{$\begin{array}{l}\text { QV } \\
\mathrm{C}\end{array}$} & $\begin{array}{c}\text { Between } \\
\text { Groups }\end{array}$ & 1.668 & 2 & .834 & $\begin{array}{c}2.66 \\
1\end{array}$ & .087 \\
\hline & $\begin{array}{l}\text { Within } \\
\text { Groups }\end{array}$ & 9.087 & 29 & .313 & & \\
\hline & Total & 10.755 & 31 & & & \\
\hline \multirow{3}{*}{$\begin{array}{l}\text { SV } \\
\text { GP }\end{array}$} & $\begin{array}{c}\text { Between } \\
\text { Groups }\end{array}$ & .497 & 2 & .249 & $\begin{array}{c}1.18 \\
6 \\
\end{array}$ & .320 \\
\hline & $\begin{array}{l}\text { Within } \\
\text { Groups }\end{array}$ & 6.080 & 29 & .210 & & \\
\hline & Total & 6.577 & 31 & & & \\
\hline
\end{tabular}

Table VII shows the significant difference in students' video game performance when grouped according to gender. It indicates that the performance of students' video games differs according to their gender. Since the p-value is $0.009<0.05$, then we reject the null hypothesis. There is a significant difference in students' video game performance when grouped according to gender.

Table VII

Significant difference in the student's video game performance when group according to gender using ANOVA

\begin{tabular}{|c|c|c|c|c|c|c|}
\hline & & $\begin{array}{l}\text { Sum of } \\
\text { Squares }\end{array}$ & df & $\begin{array}{l}\text { Mean } \\
\text { Squar } \\
\text { e }\end{array}$ & $\mathrm{F}$ & Sig. \\
\hline \multirow{3}{*}{ Con } & $\begin{array}{c}\text { Between } \\
\text { Groups }\end{array}$ & 1.108 & 1 & 1.108 & 3.649 & .066 \\
\hline & $\begin{array}{l}\text { Within } \\
\text { Groups }\end{array}$ & 9.112 & 30 & .304 & & \\
\hline & Total & 10.220 & 31 & & & \\
\hline \multirow{3}{*}{ Q } & $\begin{array}{c}\text { Between } \\
\text { Groups }\end{array}$ & 1.034 & 1 & 1.034 & 3.699 & .064 \\
\hline & $\begin{array}{l}\text { Within } \\
\text { Groups }\end{array}$ & 8.386 & 30 & .280 & & \\
\hline & Total & 9.420 & 31 & & & \\
\hline \multirow{3}{*}{ QVC } & $\begin{array}{c}\text { Between } \\
\text { Groups }\end{array}$ & 1.983 & 1 & 1.983 & 6.783 & .014 \\
\hline & $\begin{array}{l}\text { Within } \\
\text { Groups }\end{array}$ & 8.772 & 30 & .292 & & \\
\hline & Total & 10.755 & 31 & & & \\
\hline \multirow{3}{*}{ SVGP } & $\begin{array}{c}\text { Between } \\
\text { Groups }\end{array}$ & 1.344 & 1 & 1.344 & 7.704 & .009 \\
\hline & $\begin{array}{l}\text { Within } \\
\text { Groups } \\
\end{array}$ & 5.233 & 30 & .174 & & \\
\hline & Total & 6.577 & 31 & & & \\
\hline
\end{tabular}

Table VIII shows the significant difference in the students' video game performance when grouped according to grade level using the ANOVA test. Since the p-value is $0.578>0.05$, then we do not reject the null hypothesis. There is no 
significant difference in students' video game performance when grouped according to grade level. It shows that students' video game performance does not vary to its grade level.

Table VIII: Significant difference in the student's video game performance when group according to grade level using ANOVA

\begin{tabular}{|c|c|c|c|c|c|c|}
\hline & & $\begin{array}{l}\text { Sum of } \\
\text { Squares }\end{array}$ & $\mathrm{df}$ & $\begin{array}{l}\text { Mean } \\
\text { Square }\end{array}$ & $\mathrm{F}$ & Sig. \\
\hline \multirow{3}{*}{ Con } & $\begin{array}{c}\text { Between } \\
\text { Groups }\end{array}$ & .366 & 4 & .091 & .250 & .907 \\
\hline & $\begin{array}{c}\text { Within } \\
\text { Groups }\end{array}$ & 9.854 & 27 & .365 & & \\
\hline & Total & 10.220 & 31 & & & \\
\hline \multirow{3}{*}{ Q } & $\begin{array}{c}\text { Between } \\
\text { Groups }\end{array}$ & 1.480 & 4 & .370 & $\begin{array}{c}1.25 \\
8\end{array}$ & .311 \\
\hline & $\begin{array}{l}\text { Within } \\
\text { Groups }\end{array}$ & 7.940 & 27 & .294 & & \\
\hline & Total & 9.420 & 31 & & & \\
\hline \multirow{3}{*}{ QVC } & $\begin{array}{c}\text { Between } \\
\text { Groups }\end{array}$ & 1.395 & 4 & .349 & $\begin{array}{c}1.00 \\
6\end{array}$ & .422 \\
\hline & $\begin{array}{l}\text { Within } \\
\text { Groups }\end{array}$ & 9.360 & 27 & .347 & & \\
\hline & Total & 10.755 & 31 & & & \\
\hline \multirow{3}{*}{$\begin{array}{l}\text { SVG } \\
\text { P }\end{array}$} & $\begin{array}{c}\text { Between } \\
\text { Groups }\end{array}$ & .643 & 4 & .161 & .731 & .578 \\
\hline & $\begin{array}{l}\text { Within } \\
\text { Groups }\end{array}$ & 5.934 & 27 & .220 & & \\
\hline & Total & 6.577 & 31 & & & \\
\hline
\end{tabular}

RQ6. Is there a significant relationship between self-control and student's video game performance?

\section{Willpower, Determination, and Confidence}

Table IX shows the result of analyzing the significant relationship with Willpower, Determination, and Confidence towards Consistency, Quality, and Quantity, Variety, and Classification.

Table IX: Significant relationship with willpower, determination, and confidence towards consistency, quality, and quantity, variety, and classification

\begin{tabular}{|c|c|c|c|c|c|}
\hline \multirow{7}{*}{ Indicator } & Analysis & Consistency & Quality & $\begin{array}{c}\text { Quantity, } \\
\text { Variety, and } \\
\text { Classification }\end{array}$ & $\begin{array}{c}\text { Overall } \\
\text { SVGP }\end{array}$ \\
\hline \multirow{3}{*}{ WDC } & $\begin{array}{c}\text { Pearson } \\
\text { Correlation }\end{array}$ & .189 & .262 & .032 & .197 \\
\cline { 2 - 6 } & $\begin{array}{c}\text { Sig. (2- } \\
\text { tailed) }\end{array}$ & .301 & .147 & .862 & .281 \\
\cline { 2 - 6 } & $\mathrm{N}$ & 32 & 32 & 32 & 32 \\
\hline
\end{tabular}

The r-value is 0.197, which means a fragile positive relationship between willpower, determination, and confidence, and students' video game performance. Since pvalue is $0.281>0.05$, then we do not reject the null hypothesis. There is no significant relationship in the willpower, determination, and confidence, and students' video game performance.

\section{Focus and Attention}

Table $\mathrm{X}$ show the result of analyzing the significant relationship with Focus and Attention towards Consistency, Quality, and Quantity, Variety, and Classification

Table X: Significant relationship with focus and attention towards consistency, quality, and quantity, variety, and classification

\begin{tabular}{|c|c|c|c|c|c|}
\hline \multirow{2}{*}{ Indicator } & Analysis & Consistency & Quality & $\begin{array}{c}\text { Quantity, } \\
\text { Variety, and } \\
\text { Classification }\end{array}$ & $\begin{array}{c}\text { Overall } \\
\text { SVGP }\end{array}$ \\
\hline \multirow{2}{*}{ FA } & $\begin{array}{c}\text { Pearson } \\
\text { Correlation }\end{array}$ & .236 & .054 & .209 & .209 \\
\cline { 2 - 6 } & $\begin{array}{c}\text { Sig. (2- } \\
\text { tailed) }\end{array}$ & .193 & .770 & .250 & .251 \\
\cline { 2 - 6 } & $\mathrm{N}$ & 32 & 32 & 32 & 32 \\
\hline
\end{tabular}

The r-value is 0.209 , which means a weak positive relationship between focus and attention and students' video game performance. Since p-value is $0.251>0.05$, then we do not reject the null hypothesis. There is no significant relationship in the focus and attention, and students' video game performance.

\section{Calmness}

Table XI shows the result of analyzing the significant relationship with Calmness towards Consistency, Quality, and Quantity, Variety, and Classification.

Table XI: Significant relationship with calmness towards consistency, quality, and quantity, variety, and classification

\begin{tabular}{|c|c|c|c|c|c|}
\hline \multirow{5}{*}{ Indicator } & Analysis & Consistency & Quality & $\begin{array}{c}\text { Quantity, } \\
\text { Variety, and } \\
\text { Classification }\end{array}$ & $\begin{array}{c}\text { Overall } \\
\text { SVGP }\end{array}$ \\
\hline \multirow{2}{*}{$\mathrm{Cal}$} & $\begin{array}{c}\text { Pearson } \\
\text { Correlation }\end{array}$ & .085 & -.077 & .172 & .078 \\
\cline { 2 - 6 } & $\begin{array}{c}\text { Sig. (2- } \\
\text { tailed) }\end{array}$ & .644 & .677 & .346 & .671 \\
\cline { 2 - 6 } & $\mathrm{N}$ & 32 & 32 & 32 & 32 \\
\hline
\end{tabular}

The r-value is 0.078 , which means a weak positive relationship between calmness and students' video game performance. Since p-value is $0.671>0.05$, then we do not reject the null hypothesis. There is no significant relationship in the calmness and students' video game performance.

\section{Student Self Control}

Table XII shows the result of analyzing the significant relationship between Self Control and Students Video Game Performance.

Table XII. Significant relationship between self-control and students video game performance

\begin{tabular}{|c|c|c|c|}
\hline \multicolumn{2}{|c|}{} & SSC & SVGP \\
\hline \multirow{3}{*}{ SSC } & Pearson Correlation & 1 & .222 \\
\cline { 2 - 4 } & Sig. (2-tailed) & & .223 \\
\cline { 2 - 4 } & $\mathrm{N}$ & 32 & 32 \\
\hline
\end{tabular}




\begin{tabular}{|c|c|c|c|}
\hline \multirow{3}{*}{ SVGP } & Pearson Correlation & .222 & 1 \\
\cline { 2 - 4 } & Sig. (2-tailed) & .223 & \\
\cline { 2 - 4 } & $\mathrm{N}$ & 32 & 32 \\
\hline
\end{tabular}

The r-value is 0.222 , which means a weak positive relationship between the students' self-control and video game performance. Since the $p$-value is $0.223>0.05$, then we do not reject the null hypothesis. There is no significant relationship between the students' self-control and students' video game performance.

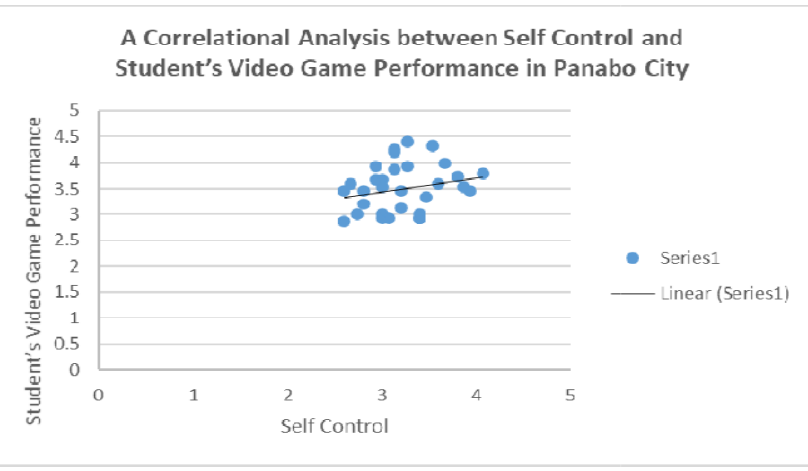

Figure 6: Scatterplot of data values

The blue dots represent the 32 coordinates, which stand as each respondent's scores in the independent and dependent variables. The black line stands for the trend of the relationship that represents the arrangement of the dots.

\section{CONCLUSIONS AND RECOMMENDATIONS}

In this study, the researcher addresses the significant relationship between self-control and student's video game performance in Panabo City. This study gets all the findings after conducting the survey questionnaire to find out the research questions. This paper also presents suggestions that will be useful for the next research.

\section{Conclusions}

- Research question number 1 displays the respondents' demographic profile, indicating an almost equal number of male and female respondents.

- In research question number 2, the result for the level of students' self-control is moderate. It proves that participants showed they had reasonable control over their behavior while playing video games.

- In research question number 3, the student's video game performance is high, indicating that the participants are relatively good at playing video games in terms of consistency, quality, quantity, variety, and classification.

- $\quad$ For research questions, numbers 4 and 5, determine if there is a significant difference between the independent and dependent variables to the moderating variables. This study's findings showed no significant difference between self-control and video game performance according to age group, gender, and grade level.

- For the last research question, the study's objective is to determine the correlation between self-control and video game performance. In this regard, the researchers concluded that there is no significant relationship between students' selfcontrol and video game performance.

\section{Recommendations}

Based on this research outcome, the researcher provides some recommendations for two parties related to this research.

For students Students should agree to polish their selfmanagement skills independently to not lose their self-control over playing video games. Also, students should practice taking a break every once in a while to settled themselves whether they are doing well in playing or not. In other cases, this could also serve as another practiced to mold the student's self-control fairly while playing video games.

For future researchers. The researcher expects other researcher to conduct a research related to video game performance and other behavioral aspects with different place or different research setting. This research could be used as references for future studies related to video game performance and student's self-control.

\section{ACKNOWLEDGEMENT}

We, the researchers from Davao del Norte State College taking up Bachelor of Science in Information Technology, are very pleased and honored to work with our adviser, Professor Glendell R. Jadraque, who helped us and being patient with us in doing our research. To our Quantitative Methods instructor, Professor Mark Van M. Buladaco, we have learned to appreciate all your comments, suggestions, and encouragement. Thank you for letting us experience making such an academic requirement - the quantitative research we could use for future purposes.

- To our statistician, Professor Ellvan M. Campos, we are grateful for being our statistician. Without your help, this research cannot be completed.

- To other members of the group, Erick Canedo, John Carlo Navarez, Joshua Lynn Cero and Ariel Alayon, this will not be possible without the support and contributions.

- Moreover, above all, to our dear Lord for giving us knowledge, guidance, power, and determination for this study's success.

\section{REFERENCES}

[1] S. I. Chiu, J. Z. Lee, and D. H. Huang, "Video game addiction in children and teenagers in Taiwan," Cyberpsychology Behav., vol. 7, no. 5, pp. 571-581, 2004, DOI: 10.1089/cpb.2004.7.571.

[2] M. Soroush, M. Hancock, and V. K. Bohns, "Self-Control in Casual Games,” 2014. 
[3] T. Ryan, S. Wen Tay, P. Ryan, and C. Anthony Ryan, "Canadian Medical Education Journal Major Contribution Systems 1 and 2 thinking processes and cognitive reflection testing in medical students," Can. Med. Educ. J., vol. 7, no. 2, pp. 97-103, 2016, [Online]. Available: http://www.cmej.ca.

[4] I. Zettler, "Self-control and academic performance: Two field studies on university citizenship behavior and counterproductive academic behavior," Learn. Individ. Differ., vol. 21, no. 1, pp. 119-123, 2011, DOI: 10.1016/j.lindif.2010.11.002.

[5] T. E. Moffitt et al., "A gradient of childhood self-control predicts health, wealth, and public safety," Proc. Natl. Acad. Sci. U. S. A., vol. 108, no. 7, pp. 2693-2698, 2011, DOI: 10.1073/pnas. 1010076108

[6] A. L. Duckworth, P. D. Quinn, and E. Tsukayama, "J Educ Psychol NIH Public Access Author Manuscript Published in final edited form as: J Educ Psychol . Author manuscript; available in PMC 2013 September 24. . 2012 May 1; 104(2): 439-451. doi:10.1037/a0026280. What No Child Left Behind Leaves Behind: The," vol. 104, no. 2, pp. 439-451, 2012, DOI: 10.1037/a0026280. What.

[7] N. Honken, P. A. Ralston, and T. R. Tretter, "Self-Control And Academic," Am. J. Eng. Educ., vol. 7, Number, no. 2, pp. 47-58, 2016.

[8] W. R. Boot, A. F. Kramer, D. J. Simons, M. Fabiani, and G. Gratton, "Acta Psychologica The effects of video game playing on attention , memory, and executive control," Acta Psychol. (Amst)., vol. 129, no. 3, pp. 387-398, 2008, DOI: 10.1016/j.actpsy.2008.09.005.

[9] Cliffsnotes.com. 2020. Descriptive/Correlational Research. [Online] Available at: https://www.cliffsnotes.com/studyguides/psychology/psychology/research-methods-in-

psychology/descriptivecorrelational-research [Accessed 2 December 2020].

[10] "Importance and use of correlational research." [Online]. Available: https://pubmed.ncbi.nlm.nih.gov/27424963/ [Accessed: 04-Jan.-2021].

[11] Porter, S., \& Carter, D. "The research process in nursing (Book, 2000) [WorldCat.org]". [Online]. Available: https://www.worldcat.org/title/research-process-innursing/oclc/41606503 [Accessed: 04-Jan.-2021].
[12] Taherdoost, Hamed, "Sampling Methods in Research Methodology; How to Choose a Sampling Technique for Research," International Journal of Academic Research in Management, 5. 18-27, 2016. [Online]. Available: https://www.researchgate.net/publication/319998246_Sampling Methods_in_Research_Methodology_How_to_Choose_a_Sampli ng_Technique_for_Research.[Accessed: Dec. 22, 2020].

[13] Walker, H. "Methods of Research. Review of Educational Research". [Online]. Available: http://www.jstor.org/stable/1169365__26(3), 323-343. [Accessed: January 3, 2021]

[14] Ezat Siddiqi, "Research Method in social science", studo.com. $2019 . \quad$ [Online]. Available: https://www.studocu.com/row/document/istanbul-aydinueniversitesi/research-method-in-social-science/lecturenotes/ezatullah-saddiqi-this-is-for-you/8509747/view._[Accessed: 22-Dec-2020].

[15] Cousineau, D, "Varieties of confidence intervals." [Online]. Available: $\quad$ https://psycnet.apa.org/record/2017-39544-003 [Accessed: 04-Jan.-2021].

[16] "What is a Survey - Definition, templates, methods, characteristics, and examples," Questionpro.com, 03-Sept-2016. [Online]. Available: https://www.questionpro.com/blog/surveys/. [Accessed: 22-Dec-2020].

[17] Yaya, Japeth A. "Choosing the right Measurement Instrument for you project: Tips to Apply" researchClue.com, 14-May-2016. [Online] Available: https://nairaproject.com/blog/measurementinstrument.html\#: : :text=Those $\% 20$ methods $\% 20$ that $\% 20$ researche rs\%20use,as\%20research\%20or\%20measurement\%20instrument. \&text $=$ These $\% 20$ are $\% 20$ instruments $\% 20$ that $\% 20$ are,all $\% 20$ types $\% 20$ of $\% 20$ research\%20methods [Accessed: 03-Jan-2021].

[18] DiscoverPhDs "What is a Research Instrument?" [Online]. Available: https://www.discoverphds.com/blog/researchinstrument [Accessed: 04-Jan.-2021].

[19] "Ethical Issues in Research," skillsyouneed.com, [Online]. Available: https://www.skillsyouneed.com/learn/researchethics.html [Accessed: 04-Jan-2021].

[20] Boyland, Michael, "The importance of ethical practice in research". [Online]. Available: https://www.sumernet.org/story/the-importance-of-ethicalpractice-in-research [Accessed: 04-Jan.-2021 